\title{
Repetitive Stimulation of the Pituitary with Growth-Hormone-Releasing Hormone Alters the Proportion of 22 and 20 Kilodalton Human-Growth Hormone Released
}

\author{
Emma A. Webb, ${ }^{1}$ P. Jane Pringle, ${ }^{1}$ Iain C. A. F. Robinson, ${ }^{2}$ and Peter C. Hindmarsh ${ }^{1}$ \\ ${ }^{1}$ Developmental Endocrinology Research Group, Institute of Child Health, University College London, 30 Guilford Street, \\ London WC1N 1EH, UK \\ ${ }^{2}$ Division of Molecular Neuroendocrinology, MRC National Institute for Medical Research, London NW7 1AA, UK
}

Correspondence should be addressed to Emma A. Webb, emmaalicewebb@yahoo.com

Received 13 February 2010; Accepted 2 April 2010

Academic Editor: Primus E. Mullis

Copyright (C) 2010 Emma A. Webb et al. This is an open access article distributed under the Creative Commons Attribution License, which permits unrestricted use, distribution, and reproduction in any medium, provided the original work is properly cited.

Background/Aims. 20 Kilodalton-hGH $(20 \mathrm{~K}-\mathrm{hGH})$ is the second most abundant pituitary GH variant after $22 \mathrm{~K}-\mathrm{hGH}$. In the steady state the proportion of $20: 22 \mathrm{~K}-\mathrm{hGH}$ appears constant; does this proportion change with repetitive somatotroph stimulation? Methods. Forty adult males were randomised to receive a GHRH(1-29) $\mathrm{NH}_{2}$ bolus $(0.5 \mu \mathrm{g} / \mathrm{kg}(n=20)$ or $1.0 \mu \mathrm{g} / \mathrm{kg}(n=20))$, preceded or followed by a saline bolus, 1 week apart. Four to six weeks later, 10 subjects received $0.5 \mu \mathrm{g} / \mathrm{kg} \mathrm{GHRH}(1-29) \mathrm{NH}_{2}$ at 0 , 60,120 , and 180 minutes. Clearance rate of 22 and $20 \mathrm{~K}$-hGH was measured in 10 subjects. Results. Total amount/proportion of $22 \mathrm{~K}-\mathrm{hGH} / 20 \mathrm{~K}-\mathrm{hGH}$ secreted was similar for both GHRH(1-29) $\mathrm{NH}_{2}$ doses. Repetitive stimulation reduced the amount of $22 \mathrm{~K}-$ hGH released whereas the amount of $20 \mathrm{~K}-\mathrm{hGH}$ did not change significantly leading to an increase in the proportion of $20 \mathrm{~K}-\mathrm{hGH}$ $(P=.05)$. Half-life of 20 and $22 \mathrm{~K}$-hGH were not significantly different $(P=.55)$. Conclusions. Repetitive stimulation of the somatotroph may alter the proportion of GH variant released.

\section{Introduction}

Growth-hormone-releasing hormone (GHRH) acts on the GHRH receptor in the pituitary gland to alter the rate of GH gene transcription, increasing the amount of growth hormone produced and released [1]. GH secretion occurs immediately following a GHRH pulse, with the amount of $\mathrm{GH}$ released in response to an intravenous bolus dependent both on dose of GHRH and on how frequently the pituitary is stimulated with GHRH. Two main forms of GH account for most of the GH released in response to GHRH stimulation [2, 3], $22 \mathrm{~K}-\mathrm{hGH}$ (191 amino acids) (approximately $75 \%$ of total secretion) and $20 \mathrm{~K}-\mathrm{hGH}$ (176 amino acids) (5-10\%) [4]. Numerous other forms are also detectable [5].

The $20 \mathrm{~K}-\mathrm{hGH}$ version lacks residues $32-46$ as a result of alternate splicing within exon 3 , but retains high biological activity on the GH receptor. It may bind less tightly to the extracellular domain of the GH receptor, but appears to have the same efficacy at the full length receptor [6]. The physiological importance of the different isoforms of GH in humans remains unclear as sensitive and specific immunoassays for $20 \mathrm{~K}-\mathrm{hGH}$ have only been recently developed [7]. 22 and $20 \mathrm{~K}-\mathrm{hGH}$ have almost identical somatogenic activity in prepubertal male and female dwarf rats [8], but this reflects interaction with rodent receptors which differ from human $\mathrm{GH}$ receptor.

It is not known what controls the ratio of splicing of 20 versus $22 \mathrm{H}$-hGH products in the pituitary, and whether they are stored as efficiently, but when secretion is studied, the $22 \mathrm{~K}: 20 \mathrm{~K}-\mathrm{hGH}$ ratio remains constant when measured over a 24 hour period and following exercise [9]. In children the percentage of the $20 \mathrm{~K}-\mathrm{hGH}$ isoform remains constant independent of age, sex, puberty, height, body mass index, and rate of GH production [10]. These observations have led to the suggestion that the overall production of $20 \mathrm{~K}-\mathrm{hGH}$ is under the same regulation as 
that of $22 \mathrm{~K}-\mathrm{hGH}$. However, recent in vitro studies using transgenic mice pituitary cell lines have specifically addressed the relative splicing efficiencies of $\mathrm{GH}$ products in the context of mutations that alter the usage of splice donor/acceptor sites in favour of a dominant negative $17.5 \mathrm{~K}-\mathrm{hGH}$ form in which exon 3 sequences are completely eliminated [11]. In this case, driving synthesis and production in an in vitro system altered the relative amounts of alternately splice products made. We have, therefore, evaluated the impact of repetitive stimulation with GHRH in humans, a stimulus that also directly drives GH synthesis, on the amount of $20: 22 \mathrm{~K}-\mathrm{hGH}$ produced.

\section{Subjects and Methods}

2.1. Subjects. 40 adult male volunteers aged 19-25 years were recruited to the study. All were of normal height (170$182 \mathrm{~cm})$, weight $(68-80 \mathrm{~kg})$, and body mass index $(22.8-$ 24.4). None of the subjects smoked and alcohol was avoided on the day before each study. Subjects fasted from midnight prior to admission the following morning to the Clinical Investigations Unit at $08.00 \mathrm{~h}$. An intravenous (iv) cannula was placed in a forearm vein to allow blood sampling and administration of iv bolus injections of GHRH(1-29) $\mathrm{NH}_{2}$ (Pfizer, Stockholm, Sweden). Subjects were allowed to rest for 60 minutes before the study commenced. Exercise and daytime napping were prohibited.

Study 1 (Dose and Intensity Studies). The 40 subjects were randomized to receive either a $\mathrm{GHRH}(1-29) \mathrm{NH}_{2}$ bolus $(0.5 \mu \mathrm{g} / \mathrm{kg}(n=20)$ or $1.0 \mu \mathrm{g} / \mathrm{kg}(n=20))$, preceded or followed by an IV bolus injection of saline. The two studies were separated in time by an interval of 1 week (Study 1 ).

Ten of the subjects who originally received a $0.5 \mu \mathrm{g} / \mathrm{kg}$ GHRH(1-29) $\mathrm{NH}_{2}$ bolus were chosen at random to participate in a second study. On a separate occasion, 4-6 weeks after the dose studies, these individuals received $0.5 \mu \mathrm{g} / \mathrm{kg}$ $\mathrm{GHRH}(1-29) \mathrm{NH}_{2}$ administered at $0,60,120$, and 180 minutes, to determine within group and within individual variation in response to $\mathrm{GHRH}(1-29) \mathrm{NH}_{2}$ stimulation, with the 20 and $22 \mathrm{kDa}$ responses 60 minutes after the first GHRH injection used to determine within group and within individual variation in response to GHRH(1-29) $\mathrm{NH}_{2}$ stimulation (Reproducibility Study). Blood samples were drawn at 10 minutes intervals for the measurement of serum 20 and $22 \mathrm{~K}-\mathrm{hGH}$ until 240 minutes. At the start of the study an additional sample was drawn for the measurement of insulin-like growth factor-1 (IGF-1). Samples were spun and separated and the serum stored at $-20^{\circ} \mathrm{C}$ prior to assay.

Study 2 (Half-Life Study). Following Study 1, 10 further (i.e., different) subjects chosen at random received a single iv bolus injection of $0.5 \mu \mathrm{g} / \mathrm{kg} \mathrm{GHRH}(1-29) \mathrm{NH}_{2}$ followed by serial blood sampling to estimate the half life of endogenously released 20 and $22 \mathrm{~K}-\mathrm{hGH}$. This study was undertaken 6-8 weeks after the completion of Study 1. In this study an additional iv cannula was inserted in the contralateral arm for infusion of Somatostatin (1-14) (Ferring Pharmaceuticals, Malmo, Sweden) $\left(20 \mu \mathrm{g} / \mathrm{m}^{2} /\right.$ hour $)$. Blood samples were drawn at 10 minutes intervals for the first 60 minutes following the bolus administration of GHRH(1-29) $\mathrm{NH}_{2}$. At this point the somatostatin (1-14) infusion was commenced and blood samples drawn at 5 minutes intervals for the following 90 minutes and assayed as in Study 1.

These studies were approved by the ethics committee's at University College London Hospitals and University College London, and written informed consent obtained from the subjects.

\section{Assays}

3.1. $20 \mathrm{~K}-\mathrm{h} G H$ Assay. $20 \mathrm{~K}-\mathrm{hGH}$ was measured by a triple antibody ELISA. Microtitre plates were coated for 7 hours at $37^{\circ} \mathrm{C}$ with a $20 \mathrm{~K}-\mathrm{hGH}$ specific mouse monoclonal antibody HGH33 in phosphate buffered saline (PBS) [12]. Prior to assay, nonspecific binding sites were blocked with $5 \%$ milk protein for 45 minutes. Standards and samples were incubated in triplicate for 90 minutes, after which a polyclonal sheep anti-hGH antibody (Scottish Antibody Production Unit, Roslin, UK) was bound to the $20 \mathrm{~K}-\mathrm{hGH} 33$ complex. This was followed by the addition of a biotinylated rabbit antigoat antiserum (DAKO Ltd., High Wycombe, UK) which recognises sheep immunoglobulins. Visualisation used an avidin:biotin complex with alkaline phosphatase as enzyme tracer (DAKO Ltd, High Wycombe, UK). The plate was developed at $24^{\circ} \mathrm{C}$ over $15-19$ hours using pnitrophenylphosphate as substrate (Sigma-Aldrich Co. LTD, Poole, UK) with the colour reaction measured at $405 \mathrm{~nm}$.

Recombinant methionyl-20 K-hGH (Genentech, San Francisco, CA, USA) (dissolved in adult human standard matrix) was used as standard at concentrations up to $10 \mathrm{ng} / \mathrm{mL}$. The minimum detection limit of the assay was $0.1 \mathrm{ng} / \mathrm{mL}$ as determined by the mean of zero + $3 \mathrm{SD}$, based on 25 repeat determinations. The withinassay coefficients of variance (CV) were $12 \%$ and $6.5 \%$ at 2.8 and $7.0 \mathrm{ng} / \mathrm{mL}$, respectively. The between-assay $\mathrm{CV}$ were $13.0 \%$ and $11.8 \%$ at 2.8 and $5.3 \mathrm{ng} / \mathrm{mL}$, respectively. The ELISA showed no detectable cross reactivity with recombinant $22 \mathrm{~K}-\mathrm{hGH}$ (International Reference Preparative 88/624; NIBSC, South Mimms, UK) at physiological concentrations $(50-100 \mathrm{ng} / \mathrm{mL})$. At very high concentrations of $22 \mathrm{~K}-\mathrm{hGH}(10 \mu \mathrm{g} / \mathrm{mL})$ cross reactivity was $0.6 \%$. At physiological concentrations, pituitary-derived hGH standard (International Standard 80/505; NIBSC) $(50-100 \mathrm{ng} / \mathrm{mL})$ showed 3\%-4\% cross-reactivity in the $20 \mathrm{~K}-\mathrm{hGH}$ assay. There was no cross reactivity at pathological concentrations of hPRL ( 4000 mU/L; North East Thames Region Immunoassay Service, St Bartholomew's Hospital, London, UK).

3.2. $22 \mathrm{~K}-\mathrm{hGH}$ Assay. Serum $22 \mathrm{~K}-\mathrm{hGH}$ was measured using the Hybritech Tandem-R immunoradiometric assay (Hybritech, Liege Belgium). This is highly specific for the $22 \mathrm{~K}-\mathrm{hGH}$ variant of hGH and showed no cross-reactivity with $20 \mathrm{~K}-\mathrm{hGH}$. The minimum detection limit of the assay was $0.19 \mathrm{ng} / \mathrm{mL}$. The within-assay CV were $10.6 \%, 5.2 \%$ and 
$4.9 \%$ at $0.5,5.5$, and $10.2 \mathrm{ng} / \mathrm{mL}$. The between-assay CV were $15.4 \%, 8.0 \%$, and $6.3 \%$ at $1.6,5.2$, and $13.8 \mathrm{ng} / \mathrm{mL}$. The assay was standardized against HS2243E (NIH, Bethesda, Maryland, USA) and has been recalibrated against International Standard 80/505 (NIBSC, South Mimms, UK).

3.3. IGF-I Assay. IGF-I was measured by a commercial immunoradiometric assay (Nichols Institute Diagnostics, San Juan Capistrano, CA, USA). This is a nonextraction method where IGF binding proteins are separated from the IGF-I by acidification of the sample and excess of IGF-II is added to block the binding proteins from recombining with the IGF-I. The within-assay CV were $4.6 \%$ and $3.3 \%$ at 6.1 and $292.5 \mathrm{ng} / \mathrm{mL}$, respectively. The between-assay CV were $15.5 \%$ and $11.3 \%$ at 88.6 and $240.4 \mathrm{ng} / \mathrm{mL}$. The standards were prepared from recombinant IGF-I and calibrated against International Reference Preparation 87/518 (NIBSC, South Mimms, UK). The minimum detection limit of the assay was $6 \mathrm{ng} / \mathrm{mL}$.

\section{Statistics}

All data were explored for the normality of their distribution and when appropriate natural-log (Ln) transformed. For this study, "total" GH refers to the sum of the 22 and $20 \mathrm{~K}-\mathrm{hGH}$ serum concentrations. The effect of the dose of GHRH(1-29) $\mathrm{NH}_{2}$ on the amount and proportion of the $\mathrm{GH}$ isoforms was compared using paired Student's $t$-test as were the group data obtained from the stimulation tests conducted on the two separate occasions 4-6 weeks apart. One way Analysis of Variance (ANOVA) with a repeated measures design was used for the study in which GHRH(129) $\mathrm{NH}_{2}$ was administered thrice. The coefficient of variation was estimated for the within individual variation for percentage of $20 \mathrm{~K}-\mathrm{hGH}$ secreted in response to GHRH(129) $\mathrm{NH}_{2}$ stimulation. Multiple linear regression was used to explore the relationship between the percentage of $20 \mathrm{~K}-\mathrm{hGH}$ released and factors such as intensity of response. The halflives of 22 and $20 \mathrm{~K}-\mathrm{hGH}$ were determined using techniques previously described by ourselves for GH [13].

\section{Results}

5.1. General. Data were available for all individuals who participated in the dose study. Nine of the 10 subjects who were selected for the triple $\mathrm{GHRH}(1-29) \mathrm{NH}_{2}$ stimulation study completed all three stimulation tests ((a) Saline, (b) $0.5 \mu \mathrm{g} / \mathrm{kg}$ baseline, (c) $0.5 \mu \mathrm{g} / \mathrm{kg} 4-6$ weeks later at 0,60 , 120 , and 180 minutes), (one individual only completed the 0 and 60 minutes time points in the triple $\mathrm{GHRH}(1-29) \mathrm{NH}_{2}$ study).

Following the bolus injection of saline there was no change in the serum 22 or $20 \mathrm{~K}-\mathrm{hGH}$ concentrations which remained low and close to the detection limit of both assays. In all studies both 22 and $20 \mathrm{~K}-\mathrm{hGH}$ concentrations were detectable above the lower limit of detection of the assay. Serum IGF-1 concentrations were $300 \mathrm{ng} / \mathrm{mL}$ (range 220375 ) in the individuals at the start of the study.
TABLe 1: Effects of $0.5 \mu \mathrm{g}$ GHRH(1-29) $\mathrm{NH}_{2}$ stimulation in 10 subjects on two separate occasions (4-6 weeks apart) on 22, 20 kilodalton and percentage of 20 kilodalton human-growth hormone secreted (concentrations measured 60 minutes after administration of $\mathrm{GHRH}(1-29) \mathrm{NH}_{2}$ ).

\begin{tabular}{lcc}
\hline & Study 1 & Study 2 \\
\hline 22 K-hGH (ng/mL) & $16.8 \pm 2.7$ & $19.2 \pm 2.0$ \\
20 K-hGH (ng/mL) & $1.2 \pm 0.3$ & $1.9 \pm 0.3$ \\
Percentage 20 K-hGH & $8.4 \pm 2.4$ & $9.8 \pm 1.7$ \\
\hline
\end{tabular}

Data shown as mean and SEM.

5.2. Study 1. There was no significant difference in the peak response to different doses of GHRH(1-29) $\mathrm{NH}_{2}$ in the total amounts of $22 \mathrm{~K}-\mathrm{hGH}$ (mean peak $22 \mathrm{~K}-\mathrm{hGH}$ to $0.5 \mu \mathrm{g} / \mathrm{kg} \mathrm{GHRH}(1-29) \mathrm{NH}_{2} 20.8 \pm 3.4 \mathrm{ng} / \mathrm{mL}$ and to $1.0 \mu \mathrm{g} / \mathrm{kg}$ GHRH$(1-29) \mathrm{NH}_{2} 22.3 \pm 2.3 \mathrm{ng} / \mathrm{mL} ; P=.37: 20 \mathrm{~K}-$ hGH $(2.6 \pm 1.5 \mathrm{ng} / \mathrm{mL}$ and $2.2 \pm 0.4 \mathrm{ng} / \mathrm{mL}$, respectively; $P=.71)$ or the proportion of $20 \mathrm{~K}-\mathrm{hGH}(10.7 \pm 2.5 \%$ and $9.4 \pm 1.6 \%$, respectively; $P=.66)$ secreted. However, the higher the peak hGH concentration, irrespective of dose, the greater the percentage of $20 \mathrm{~K}-\mathrm{hGH}$ was present $(r=0.31$; $P=.04)$.

We tested the effects of the GHRH(1-29) $\mathrm{NH}_{2}$ dose administered as a single and then further bolus injections and determined, the amounts and proportion of $20 \mathrm{~K}-\mathrm{hGH}$ released. With more frequent stimulation the amount of $22 \mathrm{~K}$-hGH released decreased significantly (One way ANOVA $F=16.4 ; P<.001)$ whereas the amount of $20 \mathrm{~K}-\mathrm{hGH}$ did not change significantly, resulting in a net increase in percentage of $20 \mathrm{~K}-\mathrm{hGH}$ present $(F=3.10 ; P=.05)$ (Figure 1, Table 2 and Figure 2). By multiple regression analysis $(R=0.29 ; P=.04)$ the intensity of response to $\mathrm{GHRH}(1-29) \mathrm{NH}_{2}$ was the major determinant of the percentage of $20 \mathrm{~K}$-hGH present $(\mathrm{B}=3.89, P=.02)$ with a much lesser contribution from the total amount of hGH released $(\mathrm{B}=0.11, P=.11)$.

The within individual coefficients of variation for $22 \mathrm{~K}$ $\mathrm{hGH}, 20 \mathrm{~K}-\mathrm{hGH}$, and the percentage of $20 \mathrm{~K}$-hGH secreted following $\mathrm{GHRH}(1-29) \mathrm{NH}_{2}$ administration on the two occasions were $19.0 \pm 4.4,24.5 \pm 9.2$, and $20.5 \pm 6.7 \%$, respectively. Group data were similar on the two occasions with no significant differences detected (Table 1).

5.3. Study 2. The initial half-lives of clearance of $22 \mathrm{~K}-\mathrm{hGH}$ $(14.2 \pm 1.1$ minutes $)$ and $20 \mathrm{~K}-\mathrm{hGH}(15.7 \pm 0.9$ minutes $)$ were not significantly different $(P=.55)$ in these subjects.

\section{Discussion}

These data demonstrate that the intensity of response to GHRH(1-29) $\mathrm{NH}_{2}$ appears to be a more important determinant of the amount of $20 \mathrm{~K}-\mathrm{hGH}$ released than the dose of GHRH(1-29) $\mathrm{NH}_{2}$ administered. In response to a repeated GHRH(1-29) $\mathrm{NH}_{2}$ stimulation lower total concentrations of hGH were achieved and a higher percentage of $20 \mathrm{~K}$ hGH was present (Figure 1, Table 2 and Figure 2). These findings have implications for clinical practice as many 


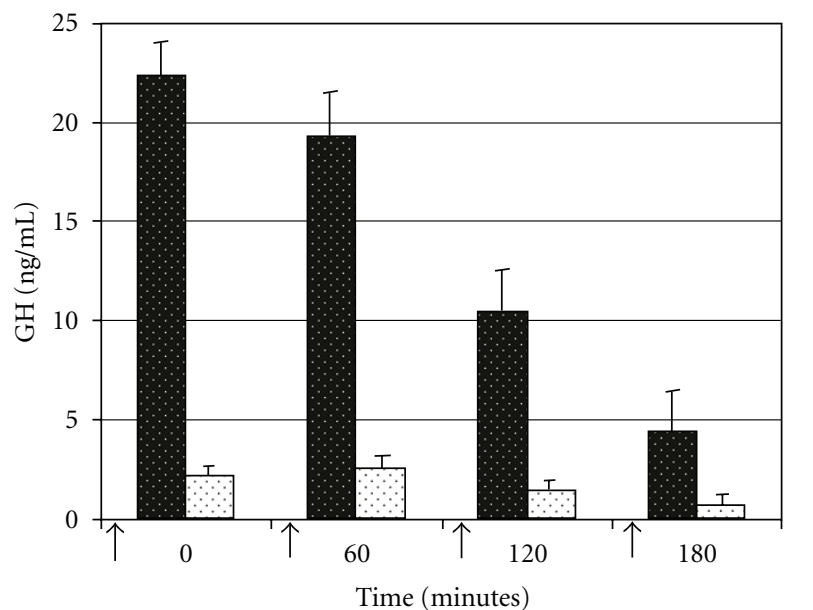

$\begin{array}{ll} & 22 \mathrm{~K} \\ \square & 20 \mathrm{~K} \\ \uparrow & \text { Times of GHRH(1-29) } \mathrm{NH}_{2} \text { administration }\end{array}$

FIGURE 1: Serum Growth-Hormone concentrations (22 K-hGH and $20 \mathrm{~K}-\mathrm{hGH}$ ) attained after repeat bolus intravenous administration of $0.5 \mu \mathrm{g}$ GHRH(1-29) $\mathrm{NH}_{2}$. Data shown as mean and SEM.

TABle 2: Absolute concentrations of $22 \mathrm{~K}-\mathrm{hGH}$ and $20 \mathrm{~K}-\mathrm{hGH}$ attained after repeat bolus intravenous administration of $0.5 \mu \mathrm{g}$ GHRH(1-29) $\mathrm{NH}_{2}$.

\begin{tabular}{lcccc}
\hline & 0 minute & 60 minutes & 120 minutes & 180 minutes \\
\hline $22 \mathrm{~K}(\mathrm{ng} / \mathrm{mL})$ & 22.3 & 19.2 & 10.4 & 4.4 \\
$20 \mathrm{~K}(\mathrm{ng} / \mathrm{mL})$ & 2.2 & 2.5 & 1.4 & 0.7 \\
\hline
\end{tabular}

endocrine centres measure peak $22 \mathrm{~K}-\mathrm{hGH}$ response to two consecutive $\mathrm{GH}$ provocation tests to diagnose growth hormone deficiency.

The overall effect of GHRH(1-29) $\mathrm{NH}_{2}$ on total hGH secretion was to reduce the concentrations achieved when the stimulus was applied with an interval of 1,2 , or 3 hours compared to the initial application of GHRH(1-29) $\mathrm{NH}_{2}$ a finding consistent with the literature [14]. This effect was more marked for $22 \mathrm{~K}-\mathrm{hGH}$ than $20 \mathrm{~K}-\mathrm{hGH}$. Our study differs from previous reports in that we have used a fixed dose of GHRH(1-29) $\mathrm{NH}_{2}$ and measured the concentration of GH variants not only in the steady state but also in response to intensive repeat stimulation [10]. We confirm that in the steady state with minimum stimulation the proportion of $20 \mathrm{~K}-\mathrm{hGH}$ found in the circulation accounts for approximately $10 \%$ of total, and that after repeated stimulation $20 \mathrm{~K}$ hGH comprises $15.7 \%$ of total hGH released. Our findings clarify previous reports which have also addressed the idea that repeated stimulation may affect the proportions of the different GH isoforms produced and released, but have been unable to distinguish isoforms produced by splicing, from other minor forms that can arise from fragmentation or deamidation, included in "non-22 K-hGH" isoforms present [15].

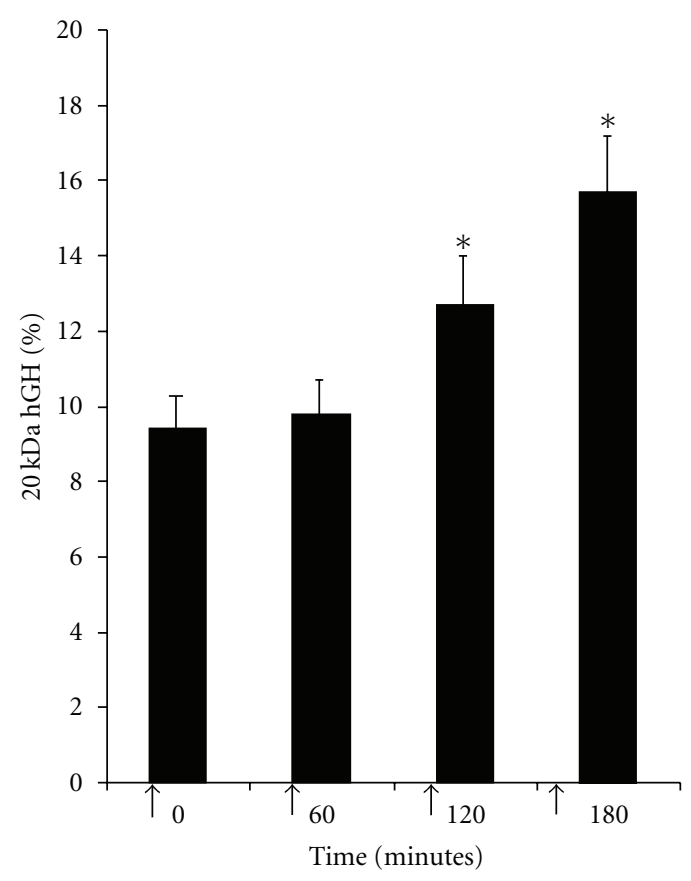

$$
\begin{aligned}
& * P=.05 \text { (significant difference in percentage serum } \\
& \text { 20K-hGH from time } 0 \text { ) } \\
& \uparrow \text { Times of GHRH(1-29) } \mathrm{NH}_{2} \text { administration }
\end{aligned}
$$

Figure 2: Percentage Serum $20 \mathrm{kDa}$ Growth-Hormone concentration after repeat bolus intravenous administration of $0.5 \mu \mathrm{g}$ GHRH(1-29) $\mathrm{NH}_{2}$. Data shown as mean and SEM.

The effect of repeated stimulation with GHRH(129) $\mathrm{NH}_{2}$ on the percentage of $20 \mathrm{~K}-\mathrm{hGH}$ present in the circulation is unlikely to be materially affected by differences in the clearance of $20 \mathrm{~K}-\mathrm{hGH}$ as the measured disappearance half-lives of $22 \mathrm{~K}-\mathrm{hGH}$ and $20 \mathrm{~K}-\mathrm{hGH}$ were similar in these subjects. This does not rule out the possibility that there could be differential binding to circulating growth hormone binding proteins in the steady state, but this is less likely to impact on our findings given the short-time frames over which repeated stimulation was performed. It is more likely that our results reflect differences in the ratio of 20 versus $22 \mathrm{~K}-\mathrm{hGH}$ products secreted under these conditions. In addition to the factors altering splicing efficiency, differences in protein stability, granule packaging, or secretion could all contribute to these differences, as could the relative release rates of different granule pools, containing newly synthesized versus previously synthesized GH [16]. It is however important to note that differences in the sensitivities of the 20 and $22 \mathrm{~K}-\mathrm{hGH}$ assays may also impact on these results with the larger decline in $22 \mathrm{~K}-\mathrm{hGH}$ which was detected possibly reflecting the difference between these two assays especially at values close to the limit of detection of the assay.

Although the biological effects of these changes may be insignificant, these observations nevertheless have implications for interpreting provocative $\mathrm{GH}$ testing in clinical practice. Many guidelines for testing the GH axis suggest 
that more than one test is undertaken [1]. In many clinical situations it is convenient to combine tests so that the two tests may be applied consecutively. Leaving aside whether this is statistically valid or not [17] there is the potential problem that the "cut-off" used to define normality on the second test should not necessarily be the same as that used for the first, especially if the components of what is being measured is changing between tests. With an increasing move towards monoclonal GH immunoassays and calibration using $22 \mathrm{~K}$ biosynthetic hGH it is obvious that total bioactive $\mathrm{GH}$ secretion will be greater than that estimated only for $22 \mathrm{~K}$ hGH. This may become important in situations of poor $\mathrm{GH}$ storage (with inadequate somatotroph mass) or constant hyperstimulation, where both reduction in secretory reserve and an increase in the proportion of $20 \mathrm{~K}-\mathrm{hGH}$ and other isoforms, may rise as hGH rises. Our observations stress the importance of considering the impact of chronic or repetitive stimulation of the $\mathrm{GH}$ axis on the production of $\mathrm{GH}$ bioactive forms that may escape detection in clinical diagnostic tests that specifically measure only maximal $22 \mathrm{~K}$ hGH secretion. These observations may have important implications for the interpretation of clinical diagnostic tests of the $\mathrm{GH}$ axis.

\section{Acknowledgment}

The authors thank Mrs. Brankica Leonard and Mrs. Caroline Dance for their technical support and Professor Mario Mellado, Centro National de Biotecnologia, Universidad Autonoma Madrid, for the supply of the $20 \mathrm{~K}-\mathrm{hGH}$ antibodies for the immunoassay.

\section{References}

[1] K. M. Attie, B.-A. Bengtsson, S. L. Blethen, et al., "Consensus guidelines for the diagnosis and treatment of growth hormone $(\mathrm{GH})$ deficiency in childhood and adolescence: summary statement of the GH research society," Journal of Clinical Endocrinology and Metabolism, vol. 85, no. 11, pp. 3990-3993, 2000.

[2] G. Baumann, "Growth hormone heterogeneity in human pituitary and plasma," Hormone Research, vol. 51, supplement 1, pp. 2-6, 1999.

[3] F. M. DeNoto, D. D. Moore, and H. M. Goodman, "Human growth hormone DNA sequence and mRNA structure: possible alternative splicing," Nucleic Acids Research, vol. 9, no. 15, pp. 3719-3730, 1981.

[4] G. E. Chapman, K. M. Rogers, T. Brittain, et al., "The 20,000 molecular weight variant of human growth hormone. Preparation and some physical and chemical properties," Journal of Biological Chemistry, vol. 256, no. 5, pp. 2395-2401, 1981.

[5] G. Baumann, M. W. Stolar, and K. Amburn, "Molecular forms of circulating growth hormone during spontaneous secretory episodes and in the basal state," Journal of Clinical Endocrinology and Metabolism, vol. 60, no. 6, pp. 1216-1220, 1985.

[6] M. Ikeda, K. Matsumoto, H. Uchida, et al., "Cellular activities of $20 \mathrm{~K}$ - and $22 \mathrm{~K}-\mathrm{hGH}$ do not necessarily correlate with their binding affinities for rat GH receptor," Hormone Research, vol. 54, no. 3, pp. 136-142, 2000.

[7] T. Tsushima, Y. Katoh, Y. Miyachi, et al., "Serum concentration of $20 \mathrm{~K}$ human growth hormone $(20 \mathrm{~K}$ hGH) measured by a specific enzyme-linked immunosorbent assay," Journal of Clinical Endocrinology and Metabolism, vol. 84, no. 1, pp. 317322, 1999.

[8] M. Ishikawa, T. Tachibana, T. Kamioka, R. Horikawa, and N. Katsumata, "Comparison of the somatogenic action of 20 $\mathrm{kDa}$ - and $22 \mathrm{kDa}$-human growth hormones in spontaneous dwarf rats," Growth Hormone and IGF Research, vol. 10, no. 4, pp. 199-206, 2000.

[9] J. D. Wallace, R. C. Cuneo, M. Bidlingmaier, et al., "The response of molecular isoforms of growth hormone to acute exercise in trained adult males," Journal of Clinical Endocrinology and Metabolism, vol. 86, no. 1, pp. 200-206, 2001.

[10] M. Ishikawa, S. Yokoya, K. Tachibana, et al., "Serum levels of 20-kilodalton human growth hormone (GH) are parallel those of 22-kilodalton human GH in normal and short children," Journal of Clinical Endocrinology and Metabolism, vol. 84, no. 1, pp. 98-104, 1999.

[11] S. Salemi, S. Yousefi, D. Lochmatter, et al., "Isolated autosomal dominant growth hormone deficiency: stimulating mutant GH-1 gene expression drives GH-1 splice-site selection, cell proliferation, and apoptosis," Endocrinology, vol. 148, no. 1, pp. 45-53, 2007.

[12] M. Mellado, J. Miguel Rodriguez-Frade, L. Kremer, and C. Martinez-Alonso, "Characterization of monoclonal antibodies specific for the human growth hormone $22 \mathrm{~K}$ and $20 \mathrm{~K}$ isoforms," Journal of Clinical Endocrinology and Metabolism, vol. 81, no. 4, pp. 1613-1618, 1996.

[13] P. C. Hindmarsh, D. R. Matthews, C. E. Brain, et al., "The half-life of exogenous growth hormone after suppression of endogenous growth hormone secretion with somatostatin," Clinical Endocrinology, vol. 30, no. 4, pp. 443-450, 1989.

[14] D. Suri, P. C. Hindmarsh, D. R. Matthews, C. E. Brain, and C. G. D. Brook, "The pituitary gland is capable of responding to two successive doses of growth hormone releasing hormone (GHRH)," Clinical Endocrinology, vol. 34, no. 1, pp. 13-17, 1991.

[15] R. Coya, J. Algorta, C. L. Boguszewski, et al., "Circulating non$22 \mathrm{kDa}$ growth hormone isoforms after a repeated GHRH stimulus in normal subjects," Growth Hormone and IGF Research, vol. 15, no. 2, pp. 123-129, 2005.

[16] R. R. Duncan, J. Greaves, U. K. Wiegand, et al., "Functional and spatial segregation of secretory vesicle pools according to vesicle age," Nature, vol. 422, no. 6928, pp. 176-180, 2003.

[17] G. Guyatt, "Evaluating diagnostic tests," in Clinical Epidemiology: How To Do Clinical Practice Research, D. Sackett and B. Haynes, Eds., pp. 273-322, Lippincott, Williams and Wilkins, Philidelphia, Pa, USA, 2005. 